\title{
Seroprevalence of Toxoplasma gondii Among Pregnant Sudanese Ladies
}

\author{
Abd Ewahid Mohammed Ahmed Elrofai ${ }^{1}$, Mohammed Ahmed Ibrahim Ahmed ${ }^{2}$, Mosab Nouraldein \\ Mohammed Hamad ${ }^{3 *}$, Nahla Ahmed Mohammed Abdurrahman ${ }^{4}$, Elamin Elawad Ali ${ }^{5}$, Wadie Mohammed \\ Yasin Elmadhoun ${ }^{6}$, Nassreden Khalid Abdelrahman ${ }^{7}$
}

\author{
${ }^{1}$ Department of Zoology, Faculty of Primary Education, Nile Valley University, Khartoum, Sudan \\ ${ }^{2}$ Department Microbiology, Faculty of Medicine, Nile Valley University, Khartoum, Sudan \\ ${ }^{3}$ Phylum of Medical Parasitology, Department of Medical Laboratory Sciences, Faculty of Health Science, Elsheikh Abdallah \\ Elbadri University, Berber, Sudan \\ ${ }^{4}$ Department Biochemistry, Faculty of Medicine, Nile Valley University, Khartoum, Sudan \\ ${ }^{5}$ Department of Obstetrics and Gynecology, Faculty of Medicine, Nile Valley University, Khartoum, Sudan \\ ${ }^{6}$ Department of Pathology, Faculty of Medicine, Sudan International University, Khartoum, Sudan \\ ${ }^{7}$ Faculty of Medical Laboratory Science, University of Al Fashir, Al Fashir, Sudan
}

\begin{abstract}
Introduction: The present study aimed to find the seroprevalence of toxoplasmosis and assess its associated risk factors among pregnant women.

Methods: This retrospective hospital-based study was carried out in the period between January 2009 and December 2010 in Eldammar, River Nile State, Sudan. Chi-square was used for trend analysis, and $P$ value was used to declare the statistical significance between the variables.

Results: A total of 383 pregnant women (age range: 16-45 years) visiting Eldammar teaching hospital and other health centers for antennal care were selected. Using latex agglutination test (LAT), 74.7\% (285/383) were positive for toxoplasmosis . ELISA (enzyme-linked immunosorbent assay) was used for IgM \& IgG confirmatory, and the results showed that 26\% (74/285) and 34.7\% (99/285) were positive for toxoplasmosis. There was a significant correlation between serological evidence of toxoplasmosis and low education level, eating undercooked meat, and drinking raw milk $(P<0.05)$.

Conclusion: There was a high prevalence of toxoplasmosis among pregnant women of the studied population. A positive correlation was reported between toxoplasmosis and low education level, eating undercooked meat, and drinking raw milk. Keywords: Toxoplasmosis, ELISA, Eldammar, Sudan
\end{abstract}

Received: September 20, 2019, Accepted: March 19, 2020, ePublished: April 1, 2020

\section{Introduction}

Toxoplasma gondii is an obligate intracellular protozoan parasite that contaminates all warm-blooded creatures. $T$. gondii infection is possibly the most well-known human infection. The situation assessed that around 33\% of the world population has been exposed to T. gondii (1). Humans are affected by eating crude or half-cooked meat contaminated with sporulated oocysts, or by exposure to infested environment (2). Other rare reasons for infection include vertical transmission to the embryo, and via organ transfer from infected donors (3).

Moms who obtained the parasite at a far off time prior to gestation has a restricted danger of inborn disease. (4). The seriousness level of inherent toxoplasmosis is conversely identified with gestational age at the hour of contamination. Throughout the primary trimester, the frequency of transmission is low yet the contamination will bring about serious inherent toxoplasmosis. Late disease is described by high transmission, yet less fetal bleakness (5). A wide scope of antagonistic pregnancy results have been portrayed including unconstrained premature delivery or stillbirth. Inherent toxoplasmosis in a newborn child next vertical transmission can prompt a broad scope of bleakness and death $(6,7)$.

Extreme baby blues and myonecrosis can result from T. gondii and Clostridium perfringens (8). There is a wide uniqueness in the frequency of intrinsic toxoplasmosis in the created nations, ranging from 1 to 10 in 10000 live births (9). Higher rates have been reported in the United Kingdom (3.4/10000) (10) and Denmark (4/10000) (11). Serological testing for Toxoplasma antibodies is broadly used $(12,13)$. 
In Arab and African nations, information on $T$. gondii during pregnancy is sparse. Additionally, most investigations are provincial. Pregnant women are not regularly examined for $T$. gondii during pregnancy, and development does not exist. Thus, the present study aimed to find the seroprevalence of toxoplasmosis and assess its associated risk factors among pregnant women (14).

\section{Materials and Methods \\ Study Design}

This retrospective hospital-based study was carried out in the period between January 2009 and December 2010 in Eldammar (300 kilometers north of Khartoum), River Nile State, Sudan.

\section{Study Population}

All pregnant women visiting Eldammar hospital and other health centers during the study period were asked to answer a structured questionnaire consisting of sociodemographic data, as well as risk factors of toxoplasmosis.

\section{Study Variables}

The dependent variable of this study was toxoplasmosis test results, because the independent variables were education level, eating undercooked meat, and drinking raw milk.

\section{Sample Size and Data Collection}

In this study, $5 \mathrm{~mL}$ of blood samples were taken from all subjects. The sera were separated in free anticoagulant plain containers and the serological evidence of toxoplasmosis were tested using latex agglutination test (LAT) SPINREACT. SA/S.A.U Ctra. Santa Coloma, Spain). Any positive result by LAT confirmed by ELISA (enzyme-linked immunosorbent assay).

\section{Data Analysis}

The Statistical Package for Social Sciences version 20 (SPSS Inc., Chicago, IL, USA) was used for data analysis of the demographic characteristics. Laboratory findings of toxoplasmosis test and demographic data were analyzed by simple descriptive statistics. Chi-square test was used to compare every two variables. A P value less than 0.05 was considered as statistically significant.

\section{Results}

A total of 383 pregnant women from different localities in Eldammar enrolled in the study. The ages of the participant ranged from 16 to 45 years. $74.4 \%$ (285/383) were positive for toxoplasmosis by latex agglutination test, and $26 \%$ (74/285), $34.7 \%$ (99/285) were positive for toxoplasmosis by ELIZA IgM \& IgG. (Table 1).

Study showed statistically significant correlation between toxoplasmosis and (low education level, eating undercooked meat, and drinking raw milk with $P$ value $(P<0.05)$. Table 2 and 3

\section{Discussion}

Seroprevalence of toxoplasmosis in the present study was $74.4 \%$ by LAT and $26 \%, 34.7 \%$ by ELISA IgM and IgG respectively which is higher than the study implemented in Atbara River Nile State-Sudan (33.6\%) by LAT (13), this due to small sample of the compared study or due difference of lifestyle between two study areas, or due to different accuracy of LAT reagent used.

The study revealed there was a statistically significant correlation between toxoplasmosis and low education level $(P=0.01, P=0.04)$, eating undercooked meat $(P=0.00$,

Table 1. The LAT and ELISA IgM \& IgG Results

\begin{tabular}{lccc}
\hline Test & Positive & Negative & Total \\
\hline LAT & $285(74.4 \%)$ & $98(25.6 \%)$ & $383(100 \%)$ \\
ELISA IgM & $74(26 \%)$ & $211(74 \%)$ & $285(100 \%)$ \\
ELISA IgG & $99(34.7 \%)$ & $186(65.3 \%)$ & $285(100 \%)$ \\
\hline
\end{tabular}

Table 2. The Correlation between Toxoplasmosis and Education Level, Eating Undercooked Meat, and Drinking Raw Milk

\begin{tabular}{lcccc}
\hline \multirow{2}{*}{ Parameter } & & \multicolumn{2}{c}{ LAT Screening } & \multirow{2}{*}{$\boldsymbol{P}$ Value } \\
\cline { 3 - 4 } & & Positive & Negative & \\
\hline Education level & $\begin{array}{c}\text { Primary school and } \\
\text { below }\end{array}$ & 213 & 58 & \\
& $\begin{array}{c}\text { Secondary school } \\
\text { and above }\end{array}$ & 72 & 40 & 0.001 \\
Eating & Yes & 226 & 56 & 0.000 \\
undercooked meat & No & 59 & 42 & \\
Drinking raw milk & Yes & 35 & 5 & 0.030 \\
\hline
\end{tabular}

Table 3. The Correlation between Toxoplasmosis and Education Level, Eating Undercooked Meat, and Drinking Raw Milk

\begin{tabular}{|c|c|c|c|c|c|c|c|}
\hline \multirow{2}{*}{ Parameter } & & \multicolumn{2}{|c|}{ ELISA IgM } & \multirow{2}{*}{$P$ value } & \multicolumn{2}{|c|}{ ELISA IgG } & \multirow{2}{*}{$P$ value } \\
\hline & & Positive & Negative & & Positive & Negative & \\
\hline \multirow{2}{*}{ Education level } & Primary school and below & 118 & 153 & \multirow{2}{*}{0.06} & 138 & 133 & \multirow{2}{*}{0.04} \\
\hline & Secondary school and above & 54 & 58 & & 59 & 53 & \\
\hline \multirow{2}{*}{$\begin{array}{l}\text { Eating } \\
\text { meat }\end{array}$} & Yes & 58 & 47 & \multirow{2}{*}{0.04} & 68 & 37 & \multirow{2}{*}{0.05} \\
\hline & No & 114 & 164 & & 129 & 149 & \\
\hline \multirow{2}{*}{ Drinking raw milk } & Yes & 19 & 21 & \multirow{2}{*}{0.01} & 24 & 16 & \multirow{2}{*}{0.03} \\
\hline & No & 153 & 190 & & 173 & 170 & \\
\hline
\end{tabular}


$P=0.05, P=0.04)$, and drinking raw milk $(P=0.03$, $P=0.03, P=0.01)$. How revealed the association between toxoplasmosis and low education level. While (14) reported a significant correlation between toxoplasmosis and drinking raw milk. Regarding the association between raw and undercooked meat and toxoplasmosis (12).

Our study suggests high education level was found protective factor to diminish the risk of transmission in high-risk populations. Molecular modalities like PCR as well as ELISA are peter than Latex Agglutination Test.

\section{Authors' Contributions}

The authors equally participated in designing the study and writing the manuscript. All authors read and approved the final version of the manuscript.

\section{Conflict of Interests}

The authors declare no conflict of interests.

\section{Ethical Approval}

The ethical approval was taken from the state ministry of health. An informed consent was taken from all participants before enrolling them in the study.

\section{Acknowledgments}

We thank all the study participants for their collaboration. The authors also wish to acknowledge the medical staff of Eldammar teaching hospital. Last but not least, we are grateful to the staff of Modern Specialized Laboratory for their technical support.

\section{References}

1. Tenter AM, Heckeroth AR, Weiss LM. Toxoplasma gondii:from animals to humans. Int J Parasitol. 2000;30(12-13):12171258. doi:10.1016/s0020-7519(00)00124-7

2. Hill D, Dubey JP. Toxoplasma gondii: transmission, diagnosisand prevention. Clin Microbiol Infect. 2002;8(10):634-640.doi:10.1046/j.1469-0691.2002.00485.x

3. Montoya JG, Liesenfeld O. Toxoplasmosis. Lancet.2004;363(9425):1965-1976. doi:10.1016/s01406736(04)16412-x

4. Cook AJ, Gilbert RE, Buffolano W, et al. Sources of Toxoplasmainfection in pregnant women: European multicentre casecontrol study. European Research Network on CongenitalToxoplasmosis. BMJ. 2000;321(7254):142-147. doi:10.1136/bmj.321.7254.142

5. Martin S. Congenital toxoplasmosis. Neonatal Netw.2001;20(4):23-30. doi:10.1891/0730-0832.20.4.23

6. Jones JL, Kruszon-Moran D, Wilson M, McQuillan G, NavinT, McAuley JB. Toxoplasma gondii infection in the UnitedStates: seroprevalence and risk factors. Am J Epidemiol.2001;154(4):357-365. doi:10.1093/aje/154.4.357

7. Alsammani MA, Ahmed SR, Alsheeha MA, Saadia Z, KhairiSA. Co-infection with Toxoplasma gondii and Clostridiumperfringens in a postpartum woman with uterine gas gangrene:a case report. J Obstet Gynaecol Res. 2012;38(7):1024-1027.doi:10.1111/j.14470756.2011.01817.x

8. Guerina NG. Congenital infection with Toxoplasmagondii. Pediatr Ann. 1994;23(3):138-142, 147-151. doi:10.3928/0090-4481-19940301-07

9. Gilbert R, Tan HK, Cliffe S, Guy E, Stanford M. SymptomaticToxoplasma infection due to congenital and postnatallyacquired infection. Arch Dis Child. 2006;91(6):495498.doi:10.1136/adc.2005.088385

10. Lebech $M$, Andersen $O$, Christensen NC, et al. Feasibility ofneonatal screening for Toxoplasma infection in the absenceof prenatal treatment. Danish Congenital Toxoplasmosis StudyGroup. Lancet. 1999; 353(9167):18341837. doi:10.1016/s0140-6736(98)11281-3

11. Remington JS, McLeod R, Thulliez $\mathrm{P}$, Desmonts G.Toxoplasmosis. In: Remington JS, Klein JO, eds. InfectiousDiseases of the Fetus and Newborn Infant. Philadelphia: WBSaunders; 2001:205-346.

12. Alsammani MA. Sero-epidemiology and risk factors forToxoplasma gondii among pregnant women in Arab andAfrican countries. J Parasit Dis. 2016;40(3):569-579. doi:10.1007/s12639-014-0558-8

13. Taha RKM, Hamad MNM, \& Taha KM, Hamad AEN. Seroprevalence of toxoplasmosis between aborted ladies inAtbara district, Sudan. MOJ Womens Health. 2019;8(1):8687. doi:10.15406/mojwh.2019.08.00217

14. Pinto-Ferreira F, Caldart ET, Pasquali AKS, Mitsuka-Breganó R, Freire RL, Navarro IT. Patterns of transmission and sources ofinfection in outbreaks of human toxoplasmosis. Emerg InfectDis. 2019;25(12):2177-2182. doi:10.3201/ eid2512.18156.

(C) 2020 The Author(s); This is an open-access article distributed under the terms of the Creative Commons Attribution License (http:// creativecommons.org/licenses/by/4.0), which permits unrestricted use, distribution, and reproduction in any medium, provided the original work is properly cited. 